\title{
Measuring the quality of management in education. Review article
}

\author{
Tito-José Crissien-Borrero; Javier Velásquez-Rodríguez; Dionicio Neira-Rodado; \\ Luis-Gabriel Turizo-Martínez
}

How to cite this article:

Crissien-Borrero, Tito-José; Velásquez-Rodríguez, Javier; Neira-Rodado, Dionicio; Turizo-Martínez, Luis-Gabriel (2019). "Measuring the quality of management in education. Review article". El profesional de la información, v. 28, n. 6, e280604.

https://doi.org/10.3145/epi.2019.nov.04

Manuscript received on $7^{\text {th }}$ February 2019 Accepted on $15^{\text {th }}$ November 2019

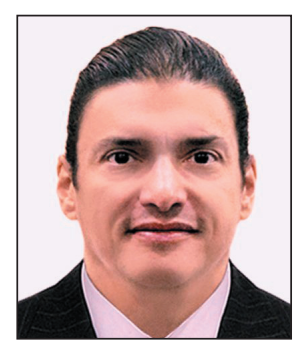

Tito-José Crissien-Borrero $\square$ https://orcid.org/0000-0002-7459-7941

Universidad de la Costa - CUC

Calle 58 \# 55 - 66.

Barranquilla, Colombia

rectoria@cuc.edu.co

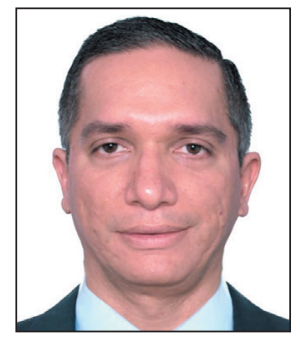

\section{Dionicio Neira-Rodado}

https://orcid.org/0000-0003-0837-7083

Universidad de la Costa - CUC

Calle 58 \# 55 - 66.

Barranquilla, Colombia

dneira1@cuc.edu.co

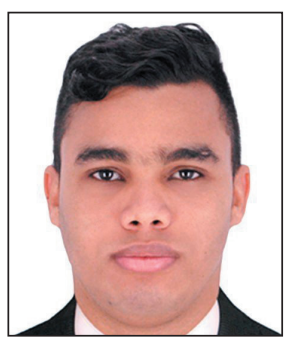

Javier Velásquez-Rodríguez

https://orcid.org/0000-0002-8257-6016

Universidad de la Costa - CUC

Calle 58 \# 55 - 66.

Barranquilla, Colombia

jvelasqu3@cuc.edu.co

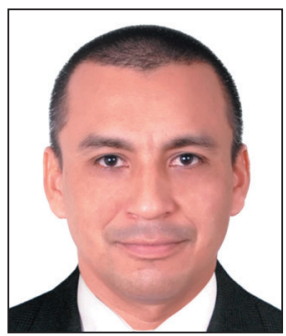

Luis-Gabriel Turizo-Martínez

https://orcid.org/0000-0002-0830-7766

Universidad de la Costa - CUC

Calle 58 \# 55 - 66.

Barranquilla, Colombia

Iturizo3@cuc.edu.co

\begin{abstract}
The objective of this study is to perform a review and contextualize the existing definitions of educational quality from the managerial point of view. We will be presenting also the factors that have been considered to support managerial decision making within educational institutions. Relevant research related to the different models for measuring educational quality and the different factors that affect this quality are discussed. The existing methodological gap of the statistical processes, the theoretical evidences and the number of investigations in every level of education are identified. The results provide a framework for future research and can become the basis for the design and construction of multidimensional models for educational management quality measurement needs of educational institutions. The results evidence also the lack of a single criterion to build the indicators, as well as the fact that there is a strong of subjectivity in the measuring processes.
\end{abstract}

\section{Keywords}

Quality in education; Quality measurement; Critical quality factors; Educational institutions; Evaluation; Audits; Assessment; Quality assurance; Higher education; Students perceptions; Indicators; Criteria; Education centers; Universities; Schools; Student experiences; Education; Literature review; Education management; Review article.

\section{Introduction}

The importance of quality in education in sustainable development is an issue that is gaining consensus among researchers and nations (Unesco, 2017b). Nevertheless, despite the fact that education has become a priority issue for nations and there have been several efforts in order to improve its quality, there is still a long way to go to achieve the educational targets proposed by the United Nations Development Program (UNDP, 2017). There are still 617 million children around the world who are not acquiring the minimum levels of learning necessary to support sustainable development goals. Taking into account the above, it is necessary to reduce this amount (Unesco, 2017a). Similarly, since 2002, Unesco 
has focused on the promotion of an equal education, considering that education is a fundamental human right for everybody, and that access to education must be accompanied by a quality of education (Unesco, 2017b).

Quality management in education is a relevant research topic, and therefore there are several studies that are being carried out in order to understand how to evaluate and measure quality of management in education (Sahney; Banwet; Karunes, 2008). It is important to point out that quality in education is a multidimensional concept, i.e., it depends on many factors. In order to improve quality in education it is important to identify the factors influencing its measurement. Therefore, this literature review aims to identify how different authors define quality in education, each of the factors that influence it and how strong each of its influences is, taking into account the different existing educational quality management approaches in each educational level.

In order to perform a complete review, the search for related papers was made using specialized databases such as Scopus, Science Direct ${ }^{1}$, and Web of Science. The time window used to do the search was between the years 2004 and 2017.

\section{Methodology}

The systematic literature review followed the three following stages proposed by Tranfield, Denyer \& Smart (2003) and implemented in the field of continuous improvement in education by Cudney, Venuthurumilli, Materla \& Antony (2018). The importance of this methodology lies on the fact that reduces the potential effect of search bias. These stages are:

- Planning the review.

- Conducting the review.

- Reporting and dissemination.

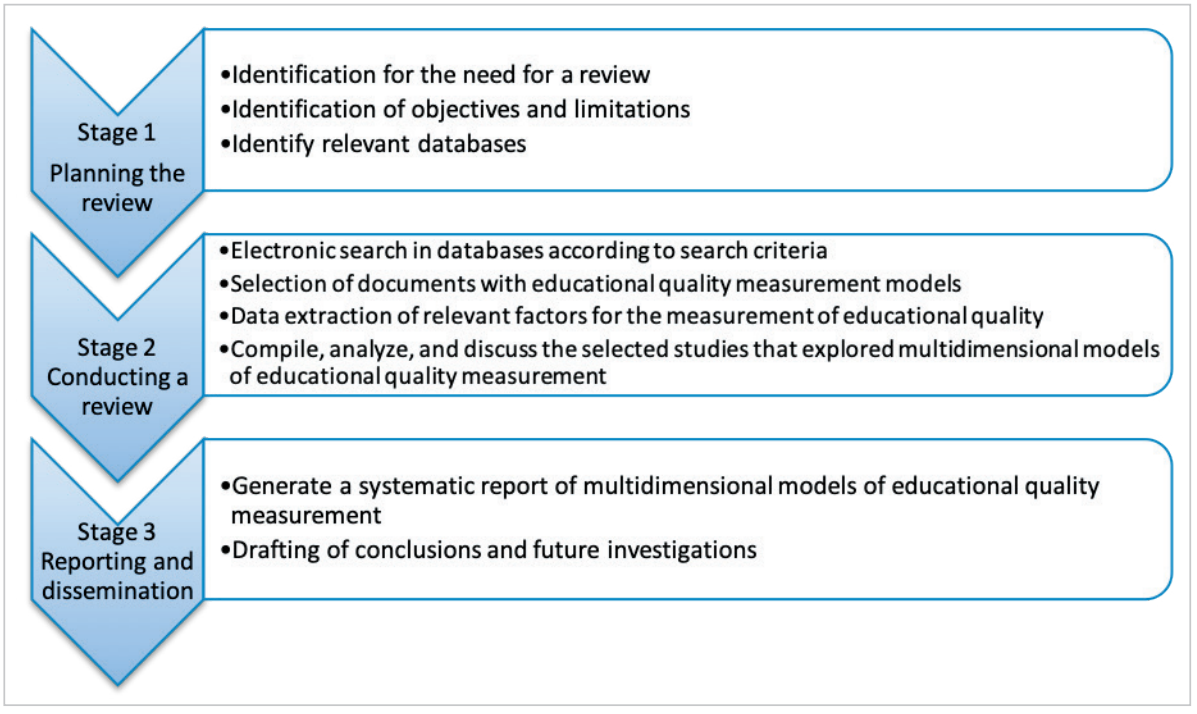

Figure 1. Schematic representation of the conducted process

A schematic representation of the conducted process in this literature review can be observed on figure 1 . This figure also specifies the activities required to fulfil each stage of the process.

\subsection{Planning the review}

In order to ensure that the data were up to date and relevant, the review was limited to articles in English-speaking outlets since 2004. To perform a complete review, the search was made exploring the following specialized databases: Scopus, ScienceDirect and Web of Science. The keywords used to do the search were: "quality in education", "multidimensional quality in education", "measurement of quality in education", "critical factors of quality in education", and "indicators of quality in education". These terms were chosen, as they cover all the topics related to the topic of measuring the Quality in Education.

\subsection{Conducting the review}

The methodologies used to measure quality in education were extracted and explained from each study. During the initial stage of the review, the following data were collected: author(s), title, year of publication, methodology of measurement used, tools used, factors considered, and results or findings of the paper.

The following section provides the literature review of the different methodologies used to measure quality in education and the factors considered in each case depending on the focus of each methodology.

\section{Literature review}

\subsection{Quality in education definitions}

Before analyzing the different definitions for quality in education it is important to point out that ISO 9000/2015 defines quality as the degree to which a set of characteristics inherent in an object (product, service, process, person, organization, system or resource) complies with the customer needs or expectations, whether they are implicit or voiced (Icontec, 2005).

The definition becomes confusing when the educational context is added, since it can be said that quality in education is a complex issue to define, because it is a very subjective term, given the different points of view from which it can be 
analyzed, in fact, there is no consensus between authors relating to the scope of the concept, causing different definitions of what quality in education is and/or implies (Doherty, 2008; Sverdlick, 2012).

Neither is there currently consensus on the factors that directly influence quality in education. Many authors have tried to associate the definition of quality in educational based on the perspective of multiple dimensions, such as: stakeholders, methods, models and systems (Kumar, 2017). In fact, Kumar concludes that, although most studies are empirically rigorous, the quality of education is very broad and there is no common framework among those studies. The number of dimensions or factors varies among the various found researches.

- From the government's point of view, quality is focused on passing rates, in standardized test scores and compliance with international standards (Tikly, 2011).

- Employers emphasize that quality is immersed in the skills and attitudes acquired by graduates.

- Students consider that quality in education is related to the learning environment and the application of the learnt concepts in their works (Akareem; Hossain, 2016).

- The academic sector focuses its vision towards the generation of applicable knowledge within society (Koslowski, 2006).

So, each stakeholder adopts a particular concept of quality in education, based on their perspective.

The analysis of quality in education implies the consideration of multiple factors or dimensions (Castillo-Riquelme; Escalona-Bustos, 2016), which implies adopting the concept from diverse perspectives. Therefore, there is no unified concept and each definition found in literature is not made in general terms but adopting a stakeholder position to define and analyze it.

Tiana-Ferrer (2006) approaches the concept of quality to the existence of several underlying dimensions, among which the efficacy, efficiency, relevance and satisfaction stand out. This author links the effectiveness to the degree of effective fulfillment of the educational objectives proposed, conceived in terms of student results through standardized tests or grades awarded by the teacher, but also relates these achievements to the resources used, acquiring a new dimension that is called efficiency. In addition, it is not only about efficacy and educational efficiency, but also the relevance of the objectives of the institution. It is also necessary the continuous questioning of the meaning, relevance and adequacy of those objectives, in order to align the actions to the search of the satisfaction of the stakeholders.

Quality in education includes multiple factors that must produce synergy (Sahney et al., 2008). Some of these are tangible factors such as students, teachers, administrative staff, physical facilities and infrastructure, teaching mode, learning outcomes, curricula and extracurricular activities. These factors are among the most relevant criteria of study and improvement approach towards the search of excellence in education.

\subsection{Determining factors of quality in education}

\subsubsection{Measuring quality in education}

Considering the difficulty of not having a consensus on the concept of quality in education, it is necessary to determine which factors affect quality in education. The difficulty of clearly distinguishing which are these factors and what impact they have for the achievement of quality is enormous. Regardless of the difficulties, it is necessary to identify these factors, since they constitute the basis for developing programs and plans for quality improvement.

The consideration or determination of these factors should be based on their predictive nature, i.e. their degree of impact on quality outcomes (national tests, for example). But existing studies rarely reach conclusive results. Consequently, the identification of quality factors is usually based on a combination of duly contrasted acquired experience, a formulation of intentions and the statement of various hypothetical propositions, only occasionally endorsed by strictly scientific studies (Murillo; Román, 2010; Tiana-Ferrer, 2006).

In order to analyze the managerial factors affecting good quality outcomes in education, it is necessary to take a look to the models that have been formulated and implemented around the world in preschool, primary, secondary, and higher education. Although being different among them, they can give notions of which are the fundamental factors when addressing quality in education.

\section{Preschool level}

In the model proposed by Jalongo et al. (2004), some factors that affect quality in preschool education are analyzed, showing a combined approach of high quality in education for preschool children, in which it identifies seven (7) dimensions that must be taken into account to satisfy the needs of a quality education:

- Philosophies and goals.

- High quality physical environments.

- Pedagogy and an effective and appropriate curriculum for children's development.

- Attention to basic and special needs.

- Respect for families and communities.

- Professionally prepared teachers and staff.

- Rigorous program evaluation. 
Jalongo et al. (2004) emphasize that the wealth of countries must be measured based on the human capital that they possess, and that there is no investment more prudent or lasting than the care and education of children.

Blanco (2011) tackles quality in initial or preschool education with an integral and multidimensional approach identifying some fundamental characteristics for an adequate educational process. This model allows to evaluate the implemented actions, incorporating the different sides that arise of the diverse sociocultural and apolitical contexts. The proposed model states the following factors considering that they have an influence on the quality in education:

- The child's activities, including the organization of the learning environment and the appropriate use of the physical resources at their disposal, making them a key element in the evaluation of educational quality.

- Integrity, all dimensions of psychomotor, physical, cognitive development, etc., are taken into account, as the synergy between the different components rather than analyzing each one separately.

- Coordination of all agents involved in the educational process, but dealing with the family as the corner stone of an appropriate educational process, i.e. quality education.

- Cultural relevance, the context in which academic activities are developed is of great importance. Cultural relevance identifies the student as an individual, and looks at their inclusion within the activities of their local, regional and national environment.

- The relevance of learning. It refers to the transcendence of the learning, taking into account its adaptation to the children needs.

- Support and training of educational agents, all this without leaving aside the teachers, who must be on a continuous improvement process.

The study conducted in Russia by Volosovets, Kirillov \& Buyanov (2017) shows three key areas or factors such as: favorable environment in the preschool educational institution (which boosts the development of a child), teacher qualifications, and additional services provided by the kindergarten. Although being an observation and measurement study of the three factors described above and not having a direct influence on the internal development of institutions, it shows that quality in education is not only measured by a single dimension. Conversely Volosovets, Kirillov \& Buyanov (2017) consider that quality in education is strongly correlated with interaction between the different areas, and that when the different factors interact properly, this will have a positive impact on the quality of education. This model has been able to identify the trend in quality in education registered in Russia, in the last years. The model has maintained the same rating scale over time (Excellent, Good, Satisfactory, Unsatisfactory) in each of the factors. It is important to highlight that the fact that there is a quantitative base of the measurements of the educational institutions supposes a starting point for the identification of key areas of quality improvement within the educational system.

\section{Secondary level}

López (2010) proposes a causal model that identifies some factors that affect the management of school organizations and the relationships between these factors, as well as the effect that management has on the quality of education of these organizations, integrating key factors such as educational leadership, planning and strategy, resource management, processes, people management, satisfaction, and results. It manages to identify key relationships among them, highlighting how school administration is fundamental for the development of educational institutions and in general points out that the factors that associate the dimensions of leadership, resources and processes, have a significant statistical effect on the variable results. The importance of the proposed model lies on the fact, that in addition to identifying the factors that affect the quality of education, the existing relationships within these are shown, which helps principals and governments to make better decisions related with the improvement of the quality of education of the system in general and of the institutions in particular.

Murillo \& Román (2010) described the challenges in the evaluation of the quality of education in Latin America, presenting an improvement model of educational quality based on 4 pillars:

- Evaluation of the teachers, the students in their schools and the functioning of the educational administrations.

- Assessment of the participation of society in the evaluation.

- Address the study of associated factors.

- Raise the need for social participation in the design of evaluation policies.

It is also important to measure the educational institution taking into account the plurality, diversity and diverse cultures that coexist in the micro-space represented by an institution. Additionally, it is important not only to measure the cognitive abilities of the student, but also, to measure the proficiency of integrating these individual abilities and make a contribution to society.

\section{Technical level}

There is also a need of measuring quality in education of technical institutions, due to their importance to supply organization with adequate qualified persons to make the technical tasks. Sahu et al. (2013) proposed a model that includes critical factors that affect quality. The model discriminates these factors in the following way:

- Roles and responsibilities of school management: This leads to the correct definition in the vision, mission, and school policies. 
- Infrastructure: Good availability of resources for a good school experience, whether books, laboratories, classrooms, auditoriums, etc.

- Training development: This refers to the acquisition of knowledge, skills and competences as a result of the teaching of vocational or practical skills and knowledge related to useful specific competences. It forms the core of learning and provides the backbone of content in technical institutes.

- Academic aspects: includes updated curriculum; Quality control teaching; Competence teaching methodology; Student-teacher relationship; Qualified instructors

- Administration in institutes: the administration plays an important role in the proper functioning of the non-teaching activities of the institutes

- Research and development: facilitation of various demands of teachers and students; Recruitment of competent personnel; Communication with interested parties; Inspection and maintenance of the installation of institutes.

- Promotion of institutional initiatives: inclusion of extracurricular activities or those activities that may generate a differential factor compared to other institutions.

- Measures of excellence of the technical institute: Consistently good academic results.

Gambhir, Wadhwa \& Grover (2016) provide a systematic methodology for constructing a quality model for the quantification of several factors in a technical institute. The model explores the concept that there are combinations of multiple processes that must be compensated collectively to improve quality of education, in addition to the teaching and learning processes of the student (Mahmood, 2008). The factors that they consider that affect quality in education are the following:

- Physical resources: Physical resources must be available, and facilities correlate positively with students' learning outcomes, hence their importance as a factor that determines quality in education.

- Teachers and staff: These are the backbone of any educational institution; the quality of academic staff adds up as an important factor of educational quality.

- Financial resources: It refers to the financial stability to achieve educational objectives and provide for the educational improvement of the institute.

- Government policies: This criterion applies to institutional management, organization and government. Each institution must have a mission and a set of objectives. The effectiveness and scope of achievement of the objectives depends on the commitment, attitude, planning and monitoring of the head's competences, incentives and self-evaluation policies.

- Learning process: Each program offered by the technical institution must properly provide instruction in basic sciences, technical topics (including general and elective), different technologies and relevant experimental training / technical skills.

- Academia interaction: Measurement of the participation of the industry within the academic curriculum of the institute, as well as its applicability within the industrial field.

- Stakeholder participation: Students, parents, teachers, professional associations, potential employers, etc., are the actors whose opinions reflect the quality of education in an institute.

The model, applied to three institutes in India, showed the relationship between each of the factors. This study concluded that using the same methodology, quality models can be developed for any type of educational institution in order to identify and compare the level of quality of education for the different programs offered by the institutes (Gambhir et al., 2016).

\section{Professional level}

In regard with the quality in education of professional institutions, Viswanadhan (2007) presents a study to prioritize factors for improving the quality of engineering education in India. Studies include multilevel decision making based on opinions of thematic experts surveyed (Viswanadhan, 2007). Therefore, it adopts a study framework that includes the following factors:

- Organization and governance.

- Financial and physical resources and their use.

- Human resources: academic staff.

- Human resources: students.

- Teaching or learning process.

- Supplementary processes.

- Relationship institution-industry.

- Research and development.

The study revealed that, for academic staff, physical and financial resources, and complementary processes require greater attention and intervention in order to achieve priority improvement, in addition to pointing out these issues as the most important among the factors that determine the quality of education. The study indicated that the organization and governability are of little importance, so their intervention is not a priority, since they are usually well-constituted areas in organizations. 
On the other hand, De-La-Orden (2009) presented a systemic model of the quality of the education system, looking at the system as a set of inputs and outputs which can be controlled, modified and classified. For De-la-Orden a quality education results from the integration of the components, which must, by definition, be interrelated and coordinated and, as a whole, aimed at fulfilling the functions and achieving the system's objectives, of which they are a part. De-LaOrden (2009) integrates isolated components such as school administration, teachers, curricular management, school environment, administrative management and financial management as factors and bases of education. The integration is made considering that these components must comply with the premises of effectiveness, efficiency and functionality.

Du et al. (2010) addressed the problem of measuring quality of education in professional institutions starting from the idea of creating a model in which the associated factors include indicators that measure all the quality potential of schools (not only measure exams) which is useful for monitoring and coordinating teaching activities. Du et al. (2010) proposed 3 factors to be evaluated:

- Participation of schools: takes into account the dynamics that the school does to be updated, taking into account the curriculum, management and teachers.

- Social participation, focusing on the level of teachers, their education and the knowledge and attitudes they have.

- Student focused: focusing directly on the skills the students will acquire throughout their stay at the institution.

In their study, Du et al. (2010) took these three factors and developed 53 indicators to measure the overall performance of the institutions in relation with this three factors. These indicators include broadly the institutional objectives, the level and involvement of teachers, the diversification and construction of curricula and their teaching methods, their participation in society, and the skills and aptitudes acquired by students with a view to their adaptability in society (Du et al., 2010).

Tsinidou, Gerogiannis \& Fitsilis (2010) conducted an empirical study to evaluate the factors that determine the quality in higher education from the point of view of the students, proposing the weights that can help in the development of a scoring model that will help to the quality control departments to quantify the students' responses to the questionnaires taking into account the preferences of the students. These factors were grouped into seven categories: academic staff, administrative services, library services, curriculum structure, location, infrastructure, and professional perspectives.

Figure 2 shows each of the associated factors and their respective related subfactors.

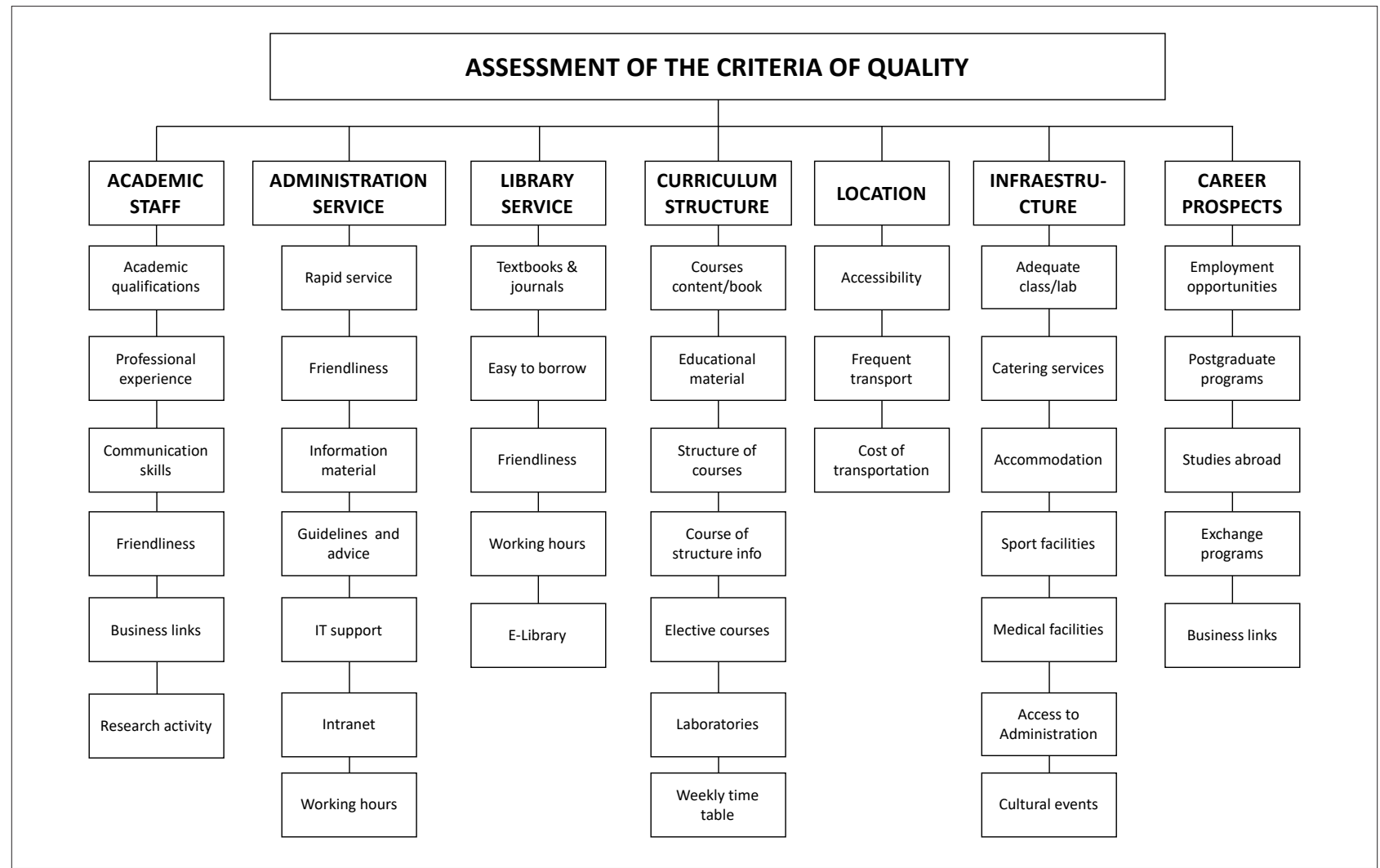

Figure 2. Quality in education measuring factors (Volosovets; Kirillov; Buyanov, 2010)

Shah (2012) considered self-evaluation in his model, emphasizing that when the participants agreed to the process of self-review, this allowed the institutions to identify areas of good practice and areas for improvement in factors such as school administration, administrative management, professional perspective and student learning outcomes, which is why it proposes different criteria that allow achieving improvement in education: 
- Superior personnel for quality assurance, so that they have the mission to coordinate areas such as: planning and strategic / operational reviews.

- Strengthened institutional governance structures. The administrative management plays a very important role in the review due to its direct contact with each of the processes that affect quality, hence its inclusion as a determining factor.

- Improved data and information management. Information that has fostered an evidence-based culture makes decisions using performance data to test and improve quality.

- Greater focus on the student's voice. Quality assurance based on performance using measures of student satisfaction, professional perspectives and educational performance.

- Use of a quality cycle.

- Improved quality control practices. It has been shown that audits have fostered a culture led by the improvement of quality assurance practices in areas such as governance, learning and teaching and research.

- Student experience.

For Lupo (2013) quality represents a horizon in which the entire European community has focused all its commitments to improve all services related to education. For this reason, he proposes a method based on a recent extension of the ServQual model (quality in services) that seeks to measure the satisfaction of students with respect to all factors that influence their education, so he uses the theory of fuzzy logic in combination with the analytical hierarchical process to effectively handle the uncertainty in the analysis of the performance of the service. Focusing on the following areas that affect educational quality:

- Academic staff: measuring the style and experience of teachers to transmit knowledge, the ability to combine theory with practical applications, the design of the course structure, the ability to use the resources at their disposal and the sustainability of the study.

- Infrastructure: measuring the physical characteristics of laboratories and classrooms such as lighting, ventilation, acoustics and the ability to house students.

- Equipment: It takes into account the quality of the resources available to the class, both the updating of the study materials and the books and software licensed by the institution.

- Support services: Support activities to help the student, the competence and courtesy of the staff, among others.

For Ahmad (2015) the quality of education is linked to the perception of students and their study experience within institutions, therefore it is necessary to quantify this satisfaction. In this sense Ahmad built a model based on seven key factors, as follows:

- Reputation / image of the university: image perceived by the stakeholders, which strongly linked with the active participation in the community, the commitment and the quality perceived by the stakeholders.

- Quality of the program or curriculum: Program structure linked to the topics to be discussed.

- Teachers and teaching quality: Teaching is a main activity of a school and it is directly related to the education and experience of the students. In quality teaching, knowledge is acquired by students in a way that allows access and opportunities in a way that it eases the ability to acquire, build and create new knowledge (Hollins, 2011).

- Student learning environment: Favorable support environments for students should be created, which are conducive to the optimal acquisition of new knowledge.

- The effective use of technology: There must be not only tools that facilitate education within the classroom, but also the proper use of these boosts the quality in education, developing new skills in students and stimulating their learning process.

- Counseling and academic counseling: Refers to additional support for the effective integration of educational nodes. It is believed that the counseling and academic counseling are among the most powerful available tools to help students succeed in their academic experience.

- Facilities: Easy access to all the facilities of the institution must be guaranteed considering its impact on students learning process.

In a particular case Shuang (2015) proposes a model for assessing the quality of higher education from the ideological and political point of view, specifically, using a fuzzy integral evaluation method that includes educational elements, educational form, educational effect and characteristic project.

- Educational elements: Organization and leadership, guaranteed conditions, construction equipment and school environment.

- Educational form: Teaching of the course, educational policy situation, social practice education, cultural construction of the campus, student management service, ideological and political education network, organizational construction group, educational quality

- Educational effect: Treatment of the campus, ideological and political quality of teachers and students, social reputation.

- Characteristic projects: Educational characteristics.

However, each factor contains subfactors that define the scope of its evaluation, so that the proposed Shuang model (Shuang, 2015) discriminates the weight or effect that each subfactor has on educational quality. 
Bezpalko, Klishevych, Liakh, and Pavliuk (2016) focused their study on the evaluation of criteria and indicators for measuring the quality of university education, from interviews with teaching staff, identifying the following criteria:

- Resources of educational activities: Including the level of professors and academic staff, students as subjects of education, the classroom material, information and support methodology.

- Organization of educational activities: includes training and education technologies and the presentation of educational achievements.

- Results of educational processes: includes the indicators of the competitiveness of graduates in the labor market and the professional achievements of graduates.

Bezpalko et al. (2016) not only proposed the series of factors described above, but also the specific weights of each of these within the evaluation process, concluding that its proposal of the fuzzy global evaluation method to address the problem of the evaluation of educational quality, is capable of effectively evaluating the quality of ideological and political education, according to the experimental results.

Ko (2017) highlights the Korean evaluation system, showing how the system migrate from the concept of internal improvement of quality without external pressure in which no significant feedback was expected, to a new culture of responsibility of educational institutions regarding the quality of education using the national accreditation system.

Therefore, Korean educational institutions have strived to improve their quality of education and other performance criteria as they develop their own indicators of institutional performance and internal systems of quality assurance. It is important to note that the Korean education system uses criteria for institutional accreditation that consist of two parts: six key criteria and thirty criteria in ten areas in five categories. The six key criteria are full-time faculty quota, new student enrollment rate, retention rate, number of facilities, proportion of educational expenses to enrollment, and proportion of scholarships to enrollment. The five categories considered by Ko (2017) are:

- Mission and administration

- Education

- Institutional community

- Educational facilities and student support

- Achievements and social responsibility

Table 1 shows the categories, areas and criteria that are taken into account for the evaluation of quality in the Korean education system.

The implementation of this methodology is enabling higher education in Korea to be transformed from its traditional role of delivering knowledge and focusing on providing well-educated human resources to the innovative Korean society, strengthening Korean competitiveness.

On the other hand, Liu (2017) clearly emphasizes the application of the Quality assessment of undergraduate education (QAUE) methodology in China, pretending in the first place to encourage universities to increase the commitment of resources to improve educational processes and improve the infrastructure of institutions. Secondly, it is intended to encourage universities to improve their management processes in order to adapt to the growth and diversification of their students. Third, the aim was to improve the processes and results of teaching and learning in order to respond to the changing world. Fourth, the intention is to motivate the universities to rethink their mission and to train students to fit into the changing external contexts. And finally, to achieve a balance between teaching and research (Liu, 2017).

All this is supported by multidisciplinary indicators that focus on the factors that affect educational quality, such as:

- Guiding principles on university operation.

- Teaching staff.

- Teaching conditions and the use of the facilities.

- Subjects and teaching reforms (structure, curriculum, practical training).

- Education management.

- Academic environment.

- Learning outcomes.

- Special features (that make a particular institution different to other institutions).

As an initial result of the application of this model of evaluation of quality in education, the change has occurred mainly in terms of commitment of resources and management of quality. Teaching facilities have been improved and spending on teaching has increased significantly. The number of teachers has grown, and the recruitment priorities of the staff have been adjusted. Quality management and internal quality monitoring systems have also been adjusted considerably (Liu, 2017). In terms of teaching and learning the improvement has been slight, but it is emphasized that this model is in its initial phase of application, so that its impact on quality improvement is expected to increase as its fully implementation is accomplished. 
Table 1. Korean categories, areas, and evaluation criteria (Ko, 2017)

\begin{tabular}{|c|c|c|}
\hline Categoríes & Areas & Criteria \\
\hline \multirow{6}{*}{ 1. Mission and management } & \multirow{3}{*}{ 1.1. Management } & 1.1.1. Educational objectives \\
\hline & & 1.1.2. Development plans and specializations \\
\hline & & 1.1.3. Self-review \\
\hline & \multirow{3}{*}{ 1.2. Finance } & 1.2.1. Financial resources \\
\hline & & 1.2.2. Budgets and management \\
\hline & & 1.2.3. Audits \\
\hline \multirow{6}{*}{ 2. Education } & \multirow{3}{*}{ 2.1. Academic programs } & 2.1.1. Organization and administration of general education programs \\
\hline & & 2.1.2. Organization and administration of major-specific education programs \\
\hline & & 2.1.3. System for enhancing academic programs \\
\hline & \multirow{3}{*}{ 2.2. Teaching and learning } & 2.2.1. Classes and academic courses \\
\hline & & 2.2.2. Academic records management \\
\hline & & 2.2.3. Support and development of teaching and learning \\
\hline \multirow{6}{*}{ 3. Education personnel } & \multirow{3}{*}{ 3.1. Faculty } & 3.1.1. Faculty recruitment systems \\
\hline & & 3.1.2. Faculty treatment and welfare \\
\hline & & 3.1.3. Support for faculty education and research \\
\hline & \multirow{3}{*}{ 3.2. Staff } & 3.2.1. Staff recruitment systems \\
\hline & & 3.2.2. Staff treatment and welfare \\
\hline & & 3.2.3. Development of staff expertise \\
\hline \multirow{6}{*}{$\begin{array}{l}\text { 4. Educational facilities and } \\
\text { student support }\end{array}$} & \multirow{3}{*}{ 4.1. Educational facilities } & 4.1.1. Classrooms and laboratories \\
\hline & & 4.1.2. Student welfare facilities \\
\hline & & 4.1.3. Libraries \\
\hline & \multirow{3}{*}{ 4.2. Student support } & 4.2.1. Student counseling system and graduate employment support \\
\hline & & 4.2.2. Suport for student activities and safety management \\
\hline & & 4.2.3. Aid to minority students \\
\hline \multirow{6}{*}{$\begin{array}{l}\text { 5. Achievements and social } \\
\text { responsibility }\end{array}$} & \multirow{3}{*}{ 5.1. University outcomes } & 5.1.1. Research performance \\
\hline & & 5.1.2. Educational achievements \\
\hline & & 5.1.3. Student satisfaction \\
\hline & \multirow{3}{*}{ 5.2. Social responsibilities } & 5.2.1. Community service policies \\
\hline & & 5.2.2. Community service outcomes \\
\hline & & 5.2.3. Contribution to community and industry \\
\hline
\end{tabular}

\section{Other education contexts}

Despite the fact that quality in education measurement models focus to a great extent on educational systems that start from the initial education of children, until they reach higher education, there are cases in which this type of methodologies goes beyond these types of institutions.

In this sense, Barbosa (2005) analyzed the quality in education from the social point of view, including factors that he considered necessary to be measured in the form of an indicator. This indicator put in context the objectives, the means, the procedures, satisfaction, absence of problems, and organizational learning. This model involves areas of evaluation such as the administration of educational institutions, the school climate and other more administrative factors such as financial management, optimization of the management of physical resources and the vision and proposed goals (Barbosa, 2005).

Udouj et al. (2017) presented the perception of managers to the accompaniment of education programs for the elderly in the US, presenting the model or the basis for measuring the quality of this type of program, taking into account:

- Program mission, objectives, and role: A program with a well-defined role will have both a clear organizational mission and an awareness of the program's environment.

- Components of an effective management system: An effective management system includes the governance guidelines, the collection of data and use, a planning process, periodic evaluation, and financial management.

- Human resources management and professional development: covering the selection of personnel, working conditions and professional development. A clear process is needed for the recruitment and hiring of qualified training and support personnel. 
- The learning environment: Programs must offer flexibility in relation with times and places, a physically safe and psychologically safe environment, and relevant learning materials and resources for adults.

Depending on the vision of the approach used (student, institution, etc.), and the analyzed institution (preschool, primary, secondary or university), the considered factors can be very diverse. Nevertheless, there are common factors in the studies found in the literature. Depending on the country of origin, some factors may be named different or divided into other sub factors. However, there is a group of factors that researchers have given greater importance in the literature in general. These factors commonly considered in the measurement models of the quality of education can be observed in Table 2 .

\subsection{Analysis of the literature}

After conducting the literature review, the articles were analyzed according to the educational level in which the models were implemented and the quantity of quality factors that were included within each measurement model. In general, from 2004 to 2017, 20 articles were published, which show a model that shapes different factors to perform an objective measurement of educational quality. Of these, 3 discussed ways of measuring at the preschool level, 2 at the secondary level, 2 at the technical level, 11 at the professional level and 2 at other educational contexts, which shows that the research of models of educational quality measurement focuses more on the professional educational level, and that publications in the other levels of education are in early stages.

Table 2. Factors and authors in quality in education

\begin{tabular}{|c|c|c|c|c|c|c|c|c|c|c|c|c|c|}
\hline$\frac{\frac{1}{0}}{\frac{5}{3}}$ & 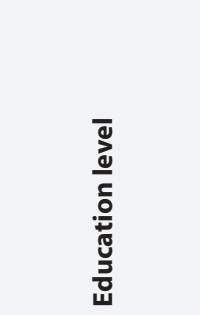 & 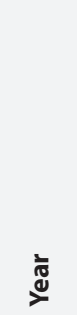 & 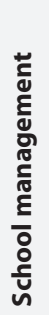 & 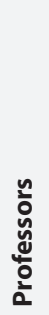 & 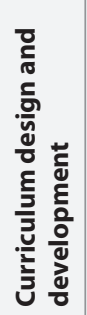 & 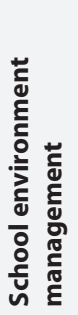 & 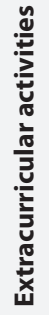 & 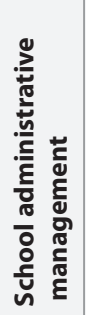 & 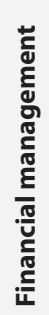 & 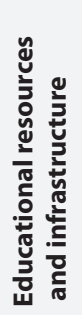 & 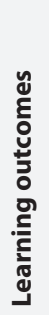 & 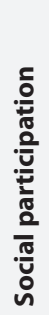 & 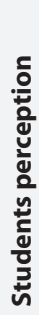 \\
\hline Jalongo et al. & \multirow{3}{*}{ Preschool level } & 2004 & $x$ & $x$ & $x$ & $x$ & $x$ & & & $x$ & & $x$ & \\
\hline Blanco & & 2011 & & $x$ & $x$ & $x$ & & & & & $x$ & $x$ & \\
\hline Volosovets, Kirillov, \& Buyanov & & 2017 & & $x$ & & $x$ & $\mathrm{x}$ & & & & & & \\
\hline López & \multirow{2}{*}{ Secondary level } & 2010 & $x$ & $x$ & & $x$ & & & $x$ & $x$ & $x$ & & \\
\hline Murillo \& Román & & 2010 & $x$ & $x$ & $x$ & & & $x$ & & & $x$ & $\mathrm{x}$ & \\
\hline Sahu, Shrivastava \& Shrivastava & \multirow{2}{*}{ Technical level } & 2013 & $x$ & $x$ & $x$ & & $\mathrm{x}$ & $x$ & & $x$ & & & \\
\hline Gambhir, Wadhwa, \& Grover & & 2016 & $x$ & $x$ & $x$ & & & & $x$ & $x$ & & $x$ & \\
\hline Viswanadhan & \multirow{11}{*}{$\begin{array}{l}\text { Professional } \\
\text { level }\end{array}$} & 2007 & $x$ & $x$ & $x$ & & $x$ & $x$ & $x$ & $x$ & $x$ & & \\
\hline De-la-Orden & & 2009 & $x$ & $x$ & $x$ & $x$ & & $x$ & $x$ & $x$ & $x$ & & \\
\hline Du, Zhao, Ma, \& Yu & & 2010 & $x$ & $x$ & $x$ & & & & & & $x$ & $x$ & \\
\hline Tsinidou, Gerogiannis, \& Fitsilis & & 2010 & & $x$ & $x$ & & & $x$ & & $x$ & & & \\
\hline Shah & & 2012 & $x$ & & & & & $x$ & & & $x$ & & $\mathrm{x}$ \\
\hline Lupo & & 2013 & & $x$ & $x$ & & & $x$ & $x$ & $x$ & & & $\mathrm{x}$ \\
\hline Ahmad & & 2015 & $\mathrm{x}$ & $\mathrm{x}$ & $x$ & $x$ & $x$ & & & $x$ & & & $x$ \\
\hline Shuang & & 2015 & $x$ & $x$ & $x$ & $x$ & $x$ & $x$ & & $x$ & & $x$ & $x$ \\
\hline Bezpalko et al. & & 2016 & & $x$ & $x$ & & & & & $x$ & $x$ & & $x$ \\
\hline Ko & & 2017 & $x$ & $x$ & $x$ & $x$ & & $x$ & & $x$ & & & \\
\hline Liu & & 2017 & $x$ & $x$ & $x$ & $x$ & $x$ & & & $x$ & $x$ & & \\
\hline Barbosa & \multirow{2}{*}{$\begin{array}{l}\text { Other educa- } \\
\text { tion contexts }\end{array}$} & 2005 & $x$ & & & $x$ & & $\mathrm{x}$ & $x$ & $x$ & & & \\
\hline Udouj et al. & & 2017 & $x$ & $x$ & & $x$ & & $x$ & & $x$ & & & \\
\hline
\end{tabular}




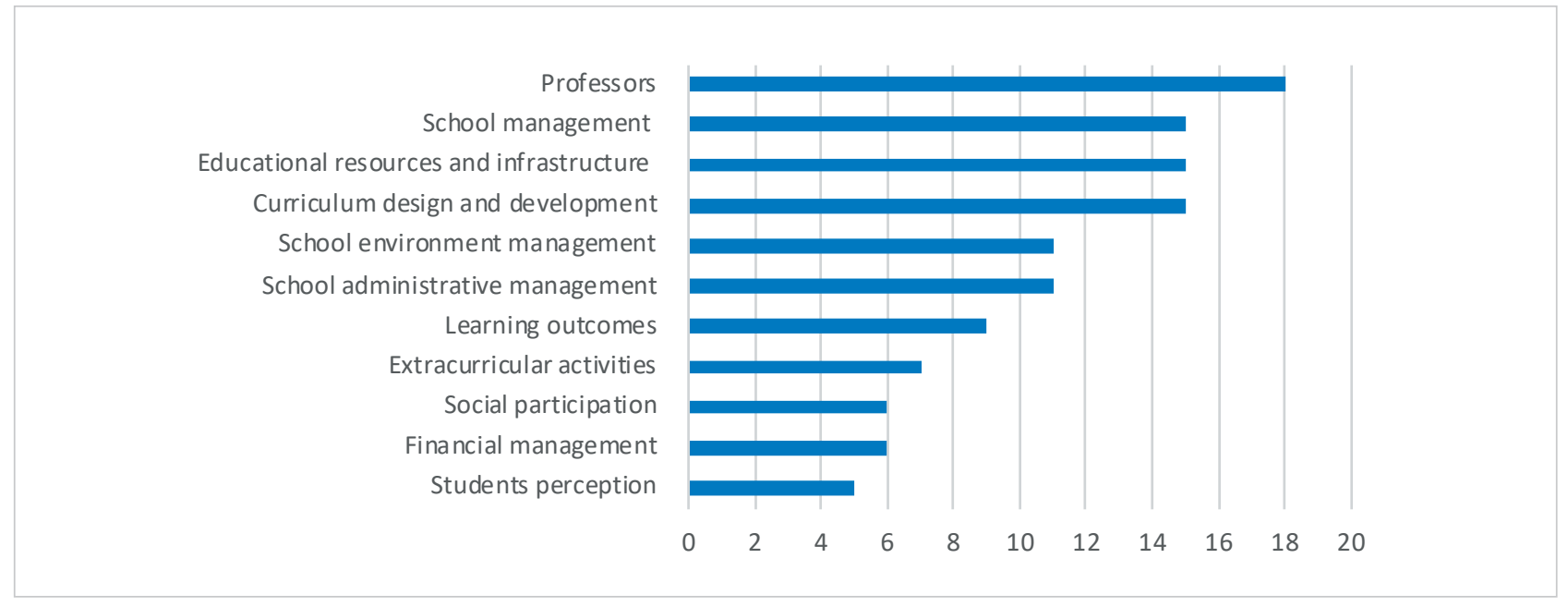

Graph 2. Number of factor inclusions per publication

The comparison of the factors that were included in each of the models shows that the professors had greater importance in the authors, since it was included in 18 of the 20 publications. This because the teaching staff plays a leading role aiming to have a good quality education. Its direct interaction with students makes it a key element to be a research focus. By focusing on improving the quality of teachers, it is expected that with better preparation and teacher training, teachers will be more competent at providing a more student-centered and appropriate curriculum, aligned with the desired outcomes of quality education (Lim-Ratnam, 2013).

However, in the second level of importance is the factor "School management", "Curriculum design and development" and "Educational resources and infrastructure" with a total of 15 inclusions in the publications, followed by "School environment management" and "School administrative management" with 11 inclusions, "Learning outcomes" with 9, "Extracurricular activities" with 7, "Social participation" and "Financial management" with 6 and "Students' perception" with 5 inclusions.

No wonder that after the teachers, the factors "School management", "Curriculum design and development" and "Educational resources and infrastructure" are the next factors considered in the publications. Since school management, being at the head of the institutions, are responsible for defining the direction they take, while the curriculum design and development is the guideline for teachers to interact with students. It is a very useful tool because it contains the set of objectives, contents, methodological criteria, and evaluation techniques that guide academic activity (Casanova, 2012). Without forgetting that "Educational resources and infrastructure" correlate positively with "Students' learning outcomes", that is, when students had adequate access to all available infrastructure facilities, their learning improved significantly (Calvo, Markauskaite, and Trigwell, 2010), which implies their importance within a quality education.

These articles can not only provide guidance to principals, teachers and educational directors about the factors that have greater importance in educational quality, but also lay the foundations for the prioritization of improvement activities within educational institutions.

\section{Conclusions}

This paper helps to understand the different definitions related to quality in education, depending on the country, the type of institution, and the aim of the study. Nevertheless, is important to point out that all the authors consider that quality in education is a multidimensional concept, i.e., it depends on many factors. The importance of this review lies on the fact that determining a proper indicator of quality in education will help the government to focus its actions in the most relevant issues of the process. And the need to understand and improve the educational processes outcomes lies on the fact that there is a global consensus among people around the world that a quality education is necessary for the sustainable development of nations (Unesco, 2017b), because sustainable development has a strong relation with the fact that a nation remains competitive (Inciarte-González, Bozo-de-Carmona; Parra-Sandoval, 2012).

All these models present clear examples that, just like the concept of educational quality itself, the way in which related factors are used as indicators varies according to the perspectives and the context of the situation. That is why, identifying the variables that best suit the needs of the population, will directly affect the outcomes of the quality of education.

Since it is essential to deepen in identifying those factors that are being left aside, given that the studies and models of existing indicators are scarce, not widely disseminated, not always rigorous from the technical and methodological point of view and, therefore, have insufficient use for decision making (Murillo; Román, 2010). 
This article identifies that despite the fact that the quality indicators at the technical, higher and other levels of education are varied, in secondary education there are methodological gaps in the development of these models, since the existing studies have been little rigorous within a technical level and have generated controversy since there are no theoretical evidences, nor statistical processes that allow affirming that the selected attributes reflect in an optimal way an objective function of educational quality nor that this function corresponds to reality.

Considering the literature review carried out, it becomes clear that there are different studies addressing the problem of measuring the quality in education, but also determining factors to be considered in order to have high quality education. Nevertheless, many of the studies focus just on some factors but do not consider all factors involved in education, yielding indicators that are not reliable.

Additionally, it is important to point out that there are different points of view when defining quality in education, and that is the first gap that must be closed, in order to improve the quality of education. In this sense we think that quality in education can be defined as the process by which an institution, through its teachers, and the support of facilities, methods, and adequate content, form its students in values, humanities and technical aspects, framed in a particular social context in order that they become individuals who contribute to the development of society and economy of their region.

The findings of this study will be useful in the different levels of education for the identification, implementation and continuous improvement of quality in education in secondary schools, in order that the construction of these quality of education measurement models will fill the gap identified, considering the needs of the country, or region in which the model will be implemented.

\section{Note}

1. The references overlap between Scopus and ScienceDirect is very high, being both Elsevier's products. Only a few no-Elsevier journals hosted by ScienceDirect are not indexed in Scopus.

\section{References}

Ahmad, Syed Zamberi (2015). "Evaluating student satisfaction of quality at international branch campuses". Assessment \& evaluation in higher education, v. 40, n. 4, pp. 488-507.

https://doi.org/10.1080/02602938.2014.925082

Akareem, Husain-Salilul; Hossain, Syed-Shahadat (2016). "Determinants of education quality: what makes students' perception different?". Open review of educational research, v. 3, n. 1, pp. 52-67. https://doi.org/10.1080/23265507.2016.1155167

Barbosa, Nanci-Rodrigues (2005). A construção de indicadores de qualidade no campo da ação cultural, pp. 18-21.

Bezpalko, Olga V.; Klishevych, Nataliia A.; Liakh, Tetiana L.; Pavliuk, Roman O. (2016). “Criteria and indicators of university education quality: The results of expert interview". The new educational review, v. 46, n. 4, pp. 61-71. https://doi.org/10.15804/tner.2016.46.4.05

Blanco, Carolina (2011). "Evaluación de la calidad en la educación inicial: una experiencia en centros educativos urbanos". Revista de investigación, v. 35, n. 72, pp. 33-49.

http://www.redalyc.org/articulo.oa?id=376140387002

Calvo, Rafael A.; Markauskaite, Lina; Trigwell, Keith (2010). "Factors affecting students' experiences and satisfaction about teaching quality in engineering". Australasian journal of engineering education, v. 16, n. 2, pp. 1-24.

https://doi.org/10.1080/22054952.2010.11464049

Casanova, María-Antonia (2012). "El diseño curricular como factor de calidad educativa”. Reice (Revista iberoamericana sobre calidad, eficacia y cambio en educación), v. 10, n. 4, pp. 6-20.

https://revistas.uam.es/index.php/reice/article/view/2984

Castillo-Riquelme, Víctor; Escalona-Bustos, Juan (2016). “Medición de la integralidad educativa. Una aproximación desde los nuevos indicadores de calidad escolar". Revista iberoamericana de evaluación educativa, v. 9, n. 2, pp. 149-165. https://doi.org/10.15366/riee2016.9.2.008

Cudney, Elizabeth A.; Venuthurumilli, Sri S. J.; Materla, Tejaswi; Antony, Jiju (2018). "Systematic review of Lean and Six Sigma approaches in higher education". Total quality management and business excellence, n. 0, pp. 1-14.

https://doi.org/10.1080/14783363.2017.1422977

De-la-Orden, Arturo (2009). “Evaluación y calidad: análisis de un modelo”. Estudios sobre educación, n. 16, pp. 17-36. https://www.unav.edu/publicaciones/revistas/index.php/estudios-sobre-educacion/article/view/22426

Doherty, Geoffrey D. (2008). “On quality in education”. Quality assurance in education, v. 16, n. 3, pp. 255-265. https://doi.org/10.1108/09684880810886268 
Du, Guo-Feng; Zhao, Yan; Ma, Chao; Yu, Si-Ping (2010). "Study on the design of co-operative education quality evaluation indicators". Applied mechanics and materials, v. 33, pp. 583-587.

https://doi.org/10.4028/www.scientific.net/AMM.33.583

Gambhir, Victor; Wadhwa, N. C.; Grover, Sandeep (2016). “Quality concerns in technical education in India: A quantifiable quality enabled model". Quality assurance in education, v. 24, n. 1, pp. 2-25.

https://doi.org/10.1108/QAE-07-2011-0040

Hollins, Etta R. (2011). "Teacher preparation for quality teaching”. Journal of teacher education, v. 62, n. 4, pp. 395-407. https://doi.org/10.1177/0022487111409415

Icontec (2005). Norma técnica Ntc-Iso colombiana 9000 - 2005, 45.

http://www.ceicmo.com/resources/documents/NTC_ISO_9000-2005.pdf

Inciarte-González, Alicia; Bozo-de-Carmona, Ana-Julia; Parra-Sandoval, María-Cristina (2012). "Reconceptualización de la calidad universitaria: un reto para América Latina". Avaliação: Revista da avaliação da educação superior (Campinas), v. 17, n. 3, pp. 637-660.

https://doi.org/10.1590/S1414-40772012000300005

Jalongo, Mary-Renck; Fennimore, Beatrice S.; Pattnaik, Jyotsna; Laverick, DeAnna M.; Brewster, Jeffrey; Mutuku, Moses (2004). "Blended perspectives: A global vision for high-quality early childhood education". Early childhood education journal, v. 32, n. 3, pp. 143-155.

https://doi.org/10.1023/B:ECEJ.0000048966.13626.be

Ko, Jang-Wan (2017). “Chapter 7 - Quality assurance system in Korean higher education”. In: The rise of quality assurance in Asian higher education, pp. 109-125. Elsevier, Chandos.

https://doi.org/10.1016/B978-0-08-100553-8.00002-1

Koslowski III, Fred A. (2006). "Quality and assessment in context: a brief review”. Quality assurance in education, v. 14, n. 3, pp. 277-288.

https://doi.org/10.1108/09684880610678586

Kumar, Goutam (2017). "Quality in higher education from different perspectives: a literature review". International journal for quality research, v. 11, n. 1, pp. 17-34.

https://doi.org/10.18421/IJQR11.01-02

Lim-Ratnam, Cristina (2013). "Tensions in defining quality pre-school education: the Singapore context". Educational review, v. 65, n. 4, pp. 416-431.

https://doi.org/10.1080/00131911.2012.707641

Liu, Shuiyun (2017). "Quality assurance and institutional transformation". In: Higher education in Asia: The Chinese experience. The rise of quality assurance in Asian higher education. Springer.

https://doi.org/10.1007/978-981-10-0789-7

López, Pablo (2010). "Variables asociadas a la gestión escolar como factores de calidad educativa”. Estudios pedagógicos (Valdivia), v. 36, n. 1, pp. 147-158.

https://doi.org/10.4067/S0718-07052010000100008

Lupo, Toni (2013). "A fuzzy ServQual based method for reliable measurements of education quality in Italian higher education area". Expert systems with applications, v. 40, n. 17, pp. 7096-7110.

https://doi.org/10.1016/j.eswa.2013.06.045

Murillo, F. Javier; Román, Marcela (2010). "Retos en la evaluación de la calidad de la educación en América Latina". Revista iberoamericana de educación, v. 53, pp. 97-120.

https://rieoei.org/RIE/article/view/559

https://doi.org/10.35362/rie530559

Qureshi, Asma-Asrar; Mahmood, Usman; Sajid, Ali (2008). "Impact of quality of service delivery in business education". In: $11^{\text {th }}$ QMOD conf. quality management and organizational development attaining sustainability from organizational excellence to sustainable excellence; 20-22 August; Helsingborg; Sweden, pp. 117-125.

http://www.ep.liu.se/ecp/033/010/ecp0803310.pdf

Sahney, Sangeeta; Banwet, Dewinder-Kumat; Karunes, Sabita (2008). "An integrated framework of indices for quality management in education: a faculty perspective". The TQM journal, v. 20, n. 5, pp. 502-519.

https://doi.org/10.1108/17542730810898467

Sahu, Anil R.; Shrivastava, Rashmi R.; Shrivastava, R. L. (2013). "Critical success factors for sustainable improvement in technical education excellence". The TQM journal, v. 25, n. 1, pp. 62-74.

https://doi.org/10.1108/17542731311286432 
Shah, Mahsood (2012). "Ten years of external quality audit in Australia: Evaluating its effectiveness and success". Assessment and evaluation in higher education, v. 37, n. 6, pp. 761-772.

https://doi.org/10.1080/02602938.2011.572154

Shuang, Guan (2015). "Ideological and political education quality evaluation using fuzzy comprehensive evaluation". In: 2015 Sixth intl conf on intelligent systems design and engineering applications (Isdea), pp. 441-444, IEEE.

https://doi.org/10.1109/ISDEA.2015.116

Sverdlick, Ingrid (2012). ¿Qué hay de nuevo en evaluación educativa? Buenos Aires: Noveduc. ISBN: 9789875383395

Tiana-Ferrer, Alejandro (2006). "Evaluación de la calidad docente de la calidad de la educación: Conceptos, modelos e instrumentos". Idea La Mancha, n. 3, pp. 54-71.

https://dialnet.unirioja.es/servlet/articulo?codigo=2141452\&orden=150169

Tikly, Leon (2011). "Towards a framework for researching the quality of education in low-income countries". Comparative education, v. 47, n. 1, pp. 1-23.

https://doi.org/10.1080/03050068.2011.541671

Tranfield, David; Denyer, David; Smart, Palminder (2003). "Towards a methodology for developing evidence-informed management knowledge by means of systematic review". British journal of management, v. 14, n. 3, pp. $207-222$. https://doi.org/10.1111/1467-8551.00375

Tsinidou, Maria; Gerogiannis, Vassilis; Fitsilis, Panos (2010). "Evaluation of the factors that determine quality in higher education: an empirical study". Quality assurance in education, v. 18, n. 3, pp. 227-244.

https://doi.org/10.1108/09684881011058669

Udouj, Gary; Grover, Kenda; Belcher, Greg; Kacirek, Kit (2017). “An investigation of perceptions of programme quality support of adult basic education programmes". Evaluation and program planning, v. 61, pp. 106-112.

https://doi.org/10.1016/j.evalprogplan.2016.11.015

UNDP (2017). Objetivos de desarrollo sostenible. Objetivo 4: Educación de calidad.

http://www.undp.org/content/undp/es/home/sustainable-development-goals/goal-4-quality-education.html

Unesco (2017a). 6 out of 10 children and adolescents are not learning a minimum in reading and math.

http://uis.unesco.org/en/news/6-out-10-children-and-adolescents-are-not-learning-minimum-reading-and-math

Unesco (2017b). Educación para el siglo XXI.

https://es.unesco.org/themes/education-21st-century

Viswanadhan, K. G. (2007). "Teachers' outlook on improvement of quality of engineering education in India". WSEAS transactions on advances in engineering education, v. 4, n. 8.

https://pdfs.semanticscholar.org/3d96/3adfd97aea62e5ad52c955cae3a8d66c9d3f.pdf

Volosovets, Tatiana; Kirillov, Ivan; Buyanov, Alexander (2017). "Evaluating the quality of preschool education in Russia". Procedia - Social and behavioral sciences, v. 237, pp. 1299-1303.

https://doi.org/10.1016/j.sbspro.2017.02.213

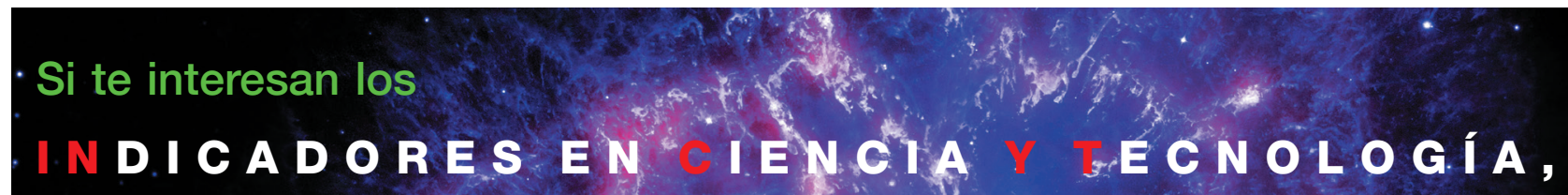

y todos los temas relaciona dos con lismédición de la ciêtria, tales como:

Análisis de citàs, Normalización dénompreste instituciones: Impacto de

la ciencia en la sociedactin radores, Sociclogia dexá ciencia, Política

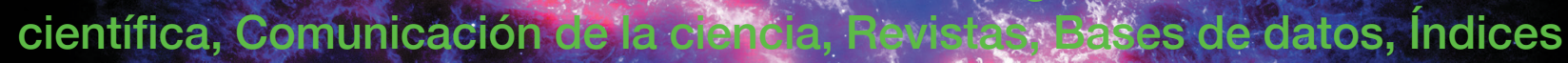

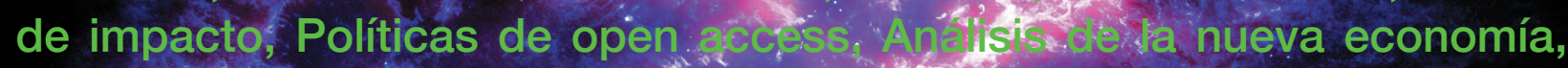
Mujer y ciencia, etc.

\section{Entonces es tu lista. Suscríbete en:}

http://wyw.rediris.es/list/info/incyt.htmI 